\title{
Prediction of EGFR and KRAS mutation in non-small cell lung cancer using quantitative ${ }^{18}$ F FDG-PET/CT metrics
}

\author{
Ryogo Minamimoto ${ }^{1}$, Mehran Jamali ${ }^{1}$, Olivier Gevaert ${ }^{1}$, Sebastian Echegaray ${ }^{1}$, \\ Amanda Khuong', Chuong D. Hoang', Joseph B. Shrager ${ }^{2}$, Sylvia K. Plevritis ${ }^{1}$, \\ Daniel L. Rubin ${ }^{1}$, Ann N. Leung ${ }^{1}$, Sandy Napel ${ }^{1}$ and Andrew Quon ${ }^{1}$ \\ ${ }^{1}$ Department of Radiology, Stanford University, Stanford, CA, USA \\ ${ }^{2}$ Department of Cardiothoracic Surgery, Stanford University, Stanford, CA, USA
}

Correspondence to: Andrew Quon, email: aquon@stanford.edu

Keywords: ${ }^{18}$ FDG-PET/CT, heterogeneity, KRAS gene mutation, EGFR gene mutation, NSCLC

Received: September 16, $2016 \quad$ Accepted: March 20, 2017 Published: May 10, 2017

Copyright: Minamimoto et al. This is an open-access article distributed under the terms of the Creative Commons Attribution License 3.0 (CC BY 3.0), which permits unrestricted use, distribution, and reproduction in any medium, provided the original author and source are credited.

\section{ABSTRACT}

This study investigated the relationship between epidermal growth factor receptor (EGFR) and Kirsten rat sarcoma viral oncogene homolog (KRAS) mutations in non-small-cell lung cancer (NSCLC) and quantitative FDG-PET/CT parameters including tumor heterogeneity. 131 patients with NSCLC underwent staging FDG-PET/ CT followed by tumor resection and histopathological analysis that included testing for the EGFR and KRAS gene mutations. Patient and lesion characteristics, including smoking habits and FDG uptake parameters, were correlated to each gene mutation. Never-smoker $(P<\mathbf{0 . 0 0 1})$ or low pack-year smoking history $(p=0.002)$ and female gender $(p=0.047)$ were predictive factors for the presence of the EGFR mutations. Being a current or former smoker was a predictive factor for the KRAS mutations $(p=0.018)$. The maximum standardized uptake value $\left(S U V_{\max }\right)$ of FDG uptake in lung lesions was a predictive factor of the EGFR mutations $(p=0.029)$, while metabolic tumor volume and total lesion glycolysis were not predictive. Amongst several tumor heterogeneity metrics included in our analysis, inverse coefficient of variation (1/COV) was a predictive factor $(p<0.02)$ of EGFR mutations status, independent of metabolic tumor diameter. Multivariate analysis showed that being a never-smoker was the most significant factor $(p<0.001)$ for the EGFR mutations in lung cancer overall. The tumor heterogeneity metric $1 / \mathrm{COV}$ and $\mathrm{SUV}_{\max }$ were both predictive for the EGFR mutations in NSCLC in a univariate analysis. Overall, smoking status was the most significant factor for the presence of the EGFR and KRAS mutations in lung cancer.

\section{INTRODUCTION}

Epidermal growth factor receptor $(E G F R)[1,2]$, Kirsten rat sarcoma viral oncogene homolog $(K R A S)$ [3] and anaplastic lymphoma kinase $(A L K)[4]$ are all significant biomarkers for the management of non-small-cell lung cancer (NSCLC). EGFR is a member of a larger family of closely related transmembrane receptor tyrosine kinases (TK), which activate cell growth and replication, differentiation and survival $[5,6]$. Mutations in the TK domain of the EGFR in NSCLC predict the response to TK inhibitors such as Gefitinib and Erlotinib [7-9]. KRAS exists downstream of EGFR and the $E G F R$ pathway is altered by $K R A S$ mutation [3]. However
$K R A S$ mutations are associated with lack of activity of the TK inhibitors [10]. $A L K$, the downstream serine-threonine kinase of EGFR signaling, rearranged tumors are not sensitive to EGFR TK inhibitors, but they are sensitive to ALK specific TK inhibitors such as Crizotinib [4]. Akt signaling is one of the main EGFR signaling pathways and includes the upregulation of glucose transporter (GLUT) 1 and 4 transporters [11, 12]. As a result, Akt activation may have a close relationship with $E G F R$ mutations and fluorodeoxyglucose (FDG) uptake in NSCLC. $[13,14]$. While the relationship between FDG uptake and EGFR mutations in NSCLC has previously been noted to have contradictory results $[15,16]$, and one notable study has shown that the KRAS mutations in lung cancer 
showed significantly higher FDG uptake than wild type (WT) cancer [17]. Tumor heterogeneity relates to both tumor development and therapeutic outcomes [18]. Moreover, clonal heterogeneity can be identified within the primary tumor ahead of identification of the metastases [19]. Intra-tumor heterogeneity appears to correlate to the EGFR mutations in NSCLC and may predict tumor responsiveness to TK inhibitors therapy [20, 21].

FDG uptake usually is not homogeneously distributed within the tumor, which can be caused by variations in necrosis [22], cellular proliferation [23] and hypoxia [24]. High intratumor heterogeneity therefore could potentially serve as a prognostic factor in NSCLC [25].

In this study, we investigate if there exists a relationship between EGFR mutations and/or KRAS mutations in NSCLC status and several FDG-PET/CT parameters such as maximum standardized uptake value $\left(\mathrm{SUV}_{\max }\right)$, metabolic tumor volume (MTV), total lesion glycolysis (TLG), and tumor heterogeneity, in order to determine the FDG-PET/CT metrics that are most predictive of a gene mutation. Subjects were recruited and enrolled in this trial if they had suspected NSCLC based on a diagnostic CT scan. Subsequently, patients underwent a battery of testing that included FDG-PET/CT scanning and gene mutation testing. Gene mutations were investigated using tissues from surgically resected tumor for all patients.

\section{RESULTS}

\section{Patient characteristics}

The total number of enrolled patients was 182 . Fiftyone cases were excluded due to any one or more of the following reasons: 1) margin of lesion not well defined (pneumonic form and central obstructive lesions on preoperative $\mathrm{CT}$ which was confirmed by a board-certified radiologist specializing in thoracic imaging), 2) gene mutation analysis not performed, and 3) histologic subtypes other than adenocarcinoma by pathological diagnosis. After the above exclusions, 131 patients (male: 86 , female: 45 , mean age \pm SD: $67 \pm 10$, range $24-81 \mathrm{yrs}$ ) met the eligibility criteria for this study and the clinical characteristics of these patients are listed in Table 1. In this study, lung cancer was more frequently identified in males $(86 / 131,65.6 \%)$, but there was no significant age difference between males and females. Lung carcinoma was primarily found in patients classified as current and former smokers (75.8\%). The characteristics of identified lung lesions are shown in Table 2. The majority of patients enrolled in this study was clinical stage of IA or IB disease (92/131, 70.2\%).

\section{Background FDG uptake in normal lung parenchyma}

Results are shown in Table 3. No significant difference was found between left and right lobe for upper area, middle area and the lower area respectively. FDG uptake in lower area was higher than upper area $(p<0.001)$ and middle area $(p<0.001)$. No significant factor (age, sex, smoking status, pack years and gene mutation) could be identified for the FDG uptake for normal lung.

\section{Gene mutation analysis}

EGFR gene mutations were confirmed in 32 of the 127 patients $(25.2 \%)$. The $K R A S$ gene mutation was confirmed in 31 of 126 patients $(24.6 \%)$.

FDG-PET/CT parameters showing a significant difference between $E G F R(+)$ and $E G F R$ - WT case were $\mathrm{SUV}_{\max }, \mathrm{TLG}, \mathrm{SD}, 1 / \mathrm{COV}$ and AUC. In cases where the metabolic tumor diameter was greater than $3 \mathrm{~cm}, E G F R$ $(+)$ and $E G F R$ - WT had no significant correlation to the metabolic tumor diameter, tumor volume and the remaining tumor heterogeneity parameters. Further, no PET parameters appeared to correlate to the presence or absence of KRAS mutations (Table 4).

The univariate analysis between several parameters and EGFR and KRAS mutation are shown in Table 5. Never-smoker (i.e. no prior smoking history), lowpack-year smoking history, and female gender were significant factors for EGFR mutation and smoker (current and former) was a significant factor for $K R A S$ mutation. The $\mathrm{SUV}_{\text {max }}$ of FDG uptake in lung lesion was significant predictor, but those of MTV and TLG were not significant. Of the multiple parameters regarding tumor heterogeneity, $1 / \mathrm{COV}$ was the only parameter that was predictive of the EGFR mutation that was not effected or dependent on the metabolic tumor volume diameter. The multivariate analysis showed smoking status was most significant predictor for EGFR mutation in lung cancer. No parameters were identified that was predictive or significantly correlated to the KRAS mutation in lung cancer. The number of cases with each index evaluated in this study are shown in Table 6 .

\section{DISCUSSION}

In the present study, we found that patients that were categorized as complete never-smoker predicted the presence of the EGFR mutation and current and former smoker predicted the presence of KRAS mutation. The SUV max $_{\text {m }}$ of FDG uptake in lung lesion were also significant parameters, while those of MTV and TLG were not significant. Of several parameters regarding tumor heterogeneity, $1 / \mathrm{COV}$ was the only significant factor which was not dependent on metabolic tumor diameter. The multivariate analysis showed never-smoker smoking status was the only significant factor for $E G F R$ mutation, and that current and former smoker status was the only significant factor for KRAS mutation in lung cancer. 
Table 1: Patient and lesion characteristics

\begin{tabular}{|c|c|c|}
\hline Characteristic & Number & Percentage \\
\hline \multicolumn{3}{|l|}{ Gender } \\
\hline Male & 86 & 65.6 \\
\hline Female & 45 & 34.4 \\
\hline Total & 131 & 100 \\
\hline \multicolumn{3}{|l|}{ Mean Age (range) } \\
\hline Male & $68 \pm 10(24-86)$ & - \\
\hline Female & $67 \pm 10(45-81)$ & - \\
\hline Total & $67 \pm 10(24-86)$ & - \\
\hline \multicolumn{3}{|l|}{ Smoking status } \\
\hline Current/former smoker & $99(22 / 77)$ & 75.8 \\
\hline Never smoker & 32 & 24.2 \\
\hline \multicolumn{3}{|l|}{ Location } \\
\hline Right lobe (RUL/RML/RLL) & $81(48 / 11 / 22)$ & 61.8 \\
\hline Left lobe (LUL/LLL) & $50(32 / 18)$ & 38.2 \\
\hline \multicolumn{3}{|l|}{ Pathology } \\
\hline Adenocarcinoma & 131 & 100.0 \\
\hline \multicolumn{3}{|l|}{ Clinical and pathological staging } \\
\hline IA & 66 & 50.4 \\
\hline IB & 26 & 19.8 \\
\hline IIA & 12 & 9.2 \\
\hline IIB & 10 & 7.6 \\
\hline IIIA & 12 & 9.2 \\
\hline IV & 2 & 1.5 \\
\hline Undefined & 3 & 2.3 \\
\hline \multicolumn{3}{|c|}{ Gene mutation (positive/negative/N/A) } \\
\hline EGFR & $32 / 95 / 4$ & - \\
\hline KRAS & $31 / 95 / 5$ & - \\
\hline
\end{tabular}

RUL: right upper lobe, RML: right middle lobe, RLL: right lower lobe, LUL: left upper lobe, LLL: left lower lobe

Table 2: FDG uptake at the normal lung field $(n=131)$

\begin{tabular}{cccccccc}
\hline Area of lung & RUF & LUF & RMF & LMF & RLF & LLF & Blood pool \\
\hline SUVmean & $0.5 \pm 0.1$ & $0.5 \pm 0.1$ & $0.4 \pm 0.2$ & $0.5 \pm 0.2$ & $0.6 \pm 0.3$ & $0.6 \pm 0.2$ & $1.7 \pm 0.4$ \\
Range & $0.2-0.9$ & $0.2-1.1$ & $0.1-1.3$ & $0.2-1.2$ & $0.1-1.8$ & $0.3-1.3$ & $0.8-2.9$ \\
\hline
\end{tabular}

RUF: right upper field, RMF: right middle field, RLF: right lower field, LUF: left upper field, LMF: left middle field, LLF: left lower field,

EGFR mutations have been linked patients with adenocarcinoma, lack of prior smoking history, females, and Asians. Our results demonstrate that never-smoking (no prior smoking history) was the most significant predictive factor for presence of the EGFR mutation, which corroborates previously observed trends [26].
The frequency of KRAS mutation is not associated with age, gender and smoking history (regardless of pack years) [27]. Therefore, KRAS mutation defines a distinct molecular subset of the disease. KRAS mutations were found in tumors from both former/current smokers and never smokers. They are rare in never smokers 
Table 3: Result in the FDG parameters

\begin{tabular}{|c|c|c|c|c|c|c|c|}
\hline \multirow{2}{*}{ FDG-PET Parameter } & \multirow{2}{*}{$\begin{array}{c}\text { Mean } \pm \text { SD } \\
\quad \text { All }\end{array}$} & \multicolumn{2}{|c|}{ EGFR mutations } & \multirow{2}{*}{$P$ value } & \multicolumn{2}{|c|}{ KRAS mutations } & \multirow{2}{*}{$P$ value } \\
\hline & & $(+)$ & $(-)$ & & $(+)$ & $(-)$ & \\
\hline $\begin{array}{l}\text { Metabolic tumor diameter } \\
(\mathrm{mm})\end{array}$ & $\begin{array}{l}33 \pm 27 \\
(8-230)\end{array}$ & $\begin{array}{c}27 \pm 13 \\
(8-53)\end{array}$ & $\begin{array}{l}34 \pm 30 \\
(8-230)\end{array}$ & 0.60 & $\begin{array}{l}36 \pm 29 \\
(8-135)\end{array}$ & $\begin{array}{l}32 \pm 27 \\
(8-230)\end{array}$ & 0.75 \\
\hline SUVmax & $\begin{array}{c}6.3 \pm 5.9 \\
(0.7-36.7)\end{array}$ & $\begin{array}{c}4.2 \pm 3.8 \\
(0.7-14.2)\end{array}$ & $\begin{array}{c}6.9 \pm 3.8 \\
(0.8-36.7)\end{array}$ & 0.009 & $\begin{array}{c}7.4 \pm 7.6 \\
(0.9-36.7)\end{array}$ & $\begin{array}{c}5.9 \pm 5.3 \\
(0.7-29.6)\end{array}$ & 0.38 \\
\hline SUVmean & $\begin{array}{c}3.8 \pm 2.7 \\
(0.7-18.9)\end{array}$ & $\begin{array}{c}3.1 \pm 2.3 \\
(0.8-10.0)\end{array}$ & $\begin{array}{c}4.0 \pm 2.9 \\
(0.7-18.9)\end{array}$ & 0.09 & $\begin{array}{l}4.2 \pm 3.6 \\
(0.7-18.9)\end{array}$ & $\begin{array}{c}6.9 \pm 3.8 \\
(0.8-36.7)\end{array}$ & 0.67 \\
\hline TLG & $\begin{array}{l}109.2 \pm 530.8 \\
(0.4-5577.5)\end{array}$ & $\begin{array}{l}17.6 \pm 34.7 \\
(0.4-162.3)\end{array}$ & $\begin{array}{l}143.4 \pm 623.5 \\
(0.5-5577.5)\end{array}$ & 0.04 & $\begin{array}{c}269.4 \pm 1028.1 \\
(0.7-5577.5)\end{array}$ & $\begin{array}{l}61.4 \pm 203.9 \\
(0.4-1725.8)\end{array}$ & 0.45 \\
\hline MTV & $\begin{array}{l}14.5 \pm 38.8 \\
(0.3-295.1)\end{array}$ & $\begin{array}{l}6.2 \pm 10.4 \\
(0.3-50.8)\end{array}$ & $\begin{array}{l}17.6 \pm 45.0 \\
(0.3-295.1)\end{array}$ & 0.29 & $\begin{array}{l}24.9 \pm 65.8 \\
(0.7-295.1)\end{array}$ & $\begin{array}{l}11.2 \pm 25.2 \\
(0.3-137.9)\end{array}$ & 0.59 \\
\hline $\mathrm{SD}(>1 \mathrm{~cm})$ & $\begin{array}{l}1.20 \pm 1.16 \\
(0.08-6.07)\end{array}$ & $\begin{array}{l}0.90 \pm 1.17 \\
(0.11-5.87)\end{array}$ & $\begin{array}{l}1.27 \pm 1.17 \\
(0.08-6.07)\end{array}$ & 0.02 & $\begin{array}{l}1.30 \pm 1.30 \\
(0.08-6.07)\end{array}$ & $\begin{array}{l}1.16 \pm 1.13 \\
(0.11-5.96)\end{array}$ & 0.65 \\
\hline $1 / \mathrm{COV}(>1 \mathrm{~cm})$ & $\begin{array}{c}4.24 \pm 2.01 \\
(1.51-17.91)\end{array}$ & $\begin{array}{l}5.10 \pm 1.89 \\
(1.70-9.09)\end{array}$ & $\begin{array}{c}4.13 \pm 2.34 \\
(1.51-17.91)\end{array}$ & 0.003 & $\begin{array}{c}4.35 \pm 2.49 \\
(1.70-15.13)\end{array}$ & $\begin{array}{c}4.34 \pm 2.21 \\
(1.51-17.91)\end{array}$ & 0.75 \\
\hline $\operatorname{AUC}(>1 \mathrm{~cm})$ & $\begin{array}{l}0.61 \pm 0.12 \\
(0.28-0.86)\end{array}$ & $\begin{array}{l}0.66 \pm 0.12 \\
(0.33-0.81)\end{array}$ & $\begin{array}{c}0.60 \pm 0.12 \\
(0.28-0.86)\end{array}$ & 0.02 & $\begin{array}{l}0.61 \pm 0.12 \\
(0.28-0.78)\end{array}$ & $\begin{array}{l}0.61 \pm 0.13 \\
(0.33-0.86)\end{array}$ & 0.96 \\
\hline $\mathrm{SD}(>2 \mathrm{~cm})$ & $\begin{array}{l}1.35 \pm 1.25 \\
(0.09-6.07)\end{array}$ & $\begin{array}{l}0.95 \pm 1.23 \\
(0.11-5.87)\end{array}$ & $\begin{array}{l}1.52 \pm 1.25 \\
(0.09-6.07)\end{array}$ & 0.006 & $\begin{array}{l}1.45 \pm 1.37 \\
(0.09-6.07)\end{array}$ & $\begin{array}{l}1.33 \pm 1.23 \\
(0.11-5.96)\end{array}$ & 0.76 \\
\hline $1 / \mathrm{COV}(>2 \mathrm{~cm})$ & $\begin{array}{l}3.96 \pm 1.53 \\
(1.51-8.93)\end{array}$ & $\begin{array}{l}4.93 \pm 1.81 \\
(0.33-8.93)\end{array}$ & $\begin{array}{l}3.59 \pm 1.25 \\
(1.51-7.67)\end{array}$ & 0.001 & $\begin{array}{l}3.85 \pm 1.36 \\
(1.69-7.67)\end{array}$ & $\begin{array}{l}3.98 \pm 1.61 \\
(1.51-8.93)\end{array}$ & 0.98 \\
\hline $\operatorname{AUC}(>2 \mathrm{~cm})$ & $\begin{array}{l}0.59 \pm 0.12 \\
(0.28-0.81)\end{array}$ & $\begin{array}{l}0.66 \pm 0.12 \\
(0.33-0.81)\end{array}$ & $\begin{array}{c}0.57 \pm 0.12 \\
(0.28-0.78)\end{array}$ & 0.007 & $\begin{array}{c}0.61 \pm 0.12 \\
(0.28-0.78)\end{array}$ & $\begin{array}{c}0.58 \pm 0.13 \\
(0.33-0.81)\end{array}$ & 0.37 \\
\hline $\mathrm{SD}(>3 \mathrm{~cm})$ & $\begin{array}{l}1.71 \pm 1.39 \\
(0.09-6.07)\end{array}$ & $\begin{array}{l}1.39 \pm 1.58 \\
(0.09-6.07)\end{array}$ & $\begin{array}{l}1.83 \pm 1.58 \\
(0.09-6.07)\end{array}$ & 0.11 & $\begin{array}{l}1.92 \pm 1.69 \\
(0.09-6.07)\end{array}$ & $\begin{array}{l}1.71 \pm 1.33 \\
(0.19-5.96)\end{array}$ & 0.72 \\
\hline $1 / \mathrm{COV}(>3 \mathrm{~cm})$ & $\begin{array}{l}3.45 \pm 1.48 \\
(1.50-8.92)\end{array}$ & $\begin{array}{l}4.03 \pm 1.73 \\
(1.70-7.42)\end{array}$ & $\begin{array}{l}3.10 \pm 1.07 \\
(1.51-7.67)\end{array}$ & 0.12 & $\begin{array}{l}3.55 \pm 1.55 \\
(1.70-7.67)\end{array}$ & $\begin{array}{l}3.25 \pm 1.23 \\
(1.51-7.42)\end{array}$ & 0.38 \\
\hline $\operatorname{AUC}(>3 \mathrm{~cm})$ & $\begin{array}{l}0.53 \pm 0.12 \\
(0.28-0.78)\end{array}$ & $\begin{array}{c}0.57 \pm 0.12 \\
(0.33-0.78)\end{array}$ & $\begin{array}{c}0.51 \pm 0.11 \\
(0.28-0.78)\end{array}$ & 0.08 & $\begin{array}{l}0.54 \pm 0.14 \\
(0.28-0.78)\end{array}$ & $\begin{array}{c}0.52 \pm 0.11 \\
(0.33-0.77)\end{array}$ & 0.68 \\
\hline
\end{tabular}

SUV: Standardized uptake value, SUVmax: Maximum SUV, TLG: Total lesion glycolysis, MTV: Metabolic tumor volume. SD: standard deviation, COV: coefficient of variation, AUC: area under the curve of the cumulative SUV-volume histogram, range shown in parenthesis.

and are less common in East Asian Vs. US/European patients [27].

Our interest was how tumor metabolism (inferred from PET imaging) could add significant value to predict gene mutations. The most popular metabolic parameter in lung cancer is the $\mathrm{SUV}_{\max }$, but $\mathrm{SUV}_{\max }$ represents just a single point within the tumor even it is easy to measure. Several papers have reported relationship between FDG uptake in lung cancer and $E G F R[17,28-31]$ and $K R A S$ gene mutations $[17,30]$. Our study appears to show a positive correlation for $\mathrm{SUV}_{\text {max }}$ as significant factor for predicating EGFR mutation. We did not find a significant correlation between SUVmax to KRAS.

TLG and MTV were not significant factors for predicting gene mutations (Table 4). This suggests that gene mutation can occur regardless of the size or volume of lung lesion since TLG and MTV are proportional to tumor size. Therefore conventional assessment based on tumor size appeared to be limited for the prediction of gene mutation in lung cancer. One of the novelties of our study was to evaluate the relationship between tumor heterogeneity and gene mutation (Table 4). In regards to tumor heterogeneity, prior studies commonly include both partial volume effects and noise as heterogeneity [32]. Several FDG-PET/CT metrics regarding tumor heterogeneity correlated to EGFR mutation, but $1 / \mathrm{COV}$ appears to be the most reliable due to the lack of dependence on lesion size.

Yip et al. investigated the association between FDG-PET based radiomic features and somatic mutations in NSCLC. A significant relationship could be seen in SUVmax, MTV, minimum of SUV and several indexes obtained from texture based analysis for predicting EGFR mutations; on the other hand no index could be seen as predicting of KRAS mutations [33].

The key trend of representing tumor heterogeneity is texture based analysis $[34,35]$. Several indexes were shown to have significant relationship with predicting EGFR gene mutations [33]. We did not adapt these methods in this study, because the methodology has not been standardized in terms of the software and indexes as described in each article. The 1/COV appears to have limited reliability in their robustness and repeatability, however we adopted PET edge method for tracing the edge of FDG uptake in tumor in order to minimize the measurement variance by the observer [36, 37]. 
Table 4: Association between each indexes and EGFR and $K R A S$ mutations status based on univariate analysis ( $p$-values)

\begin{tabular}{|c|c|c|c|}
\hline Index & EGFR mutations & KRAS mutations & Association \\
\hline Age & 0.70 & 0.79 & - \\
\hline Gender & 0.047 & 0.06 & Female with EGFR mutations \\
\hline Cancer staging & 0.54 & 0.68 & - \\
\hline $\begin{array}{l}\text { Smoking status } \\
\text { (Current / former smoker vs never-smoker) }\end{array}$ & $<0.001$ & 0.018 & $\begin{array}{l}\text { Never-smoker with EGFR mutations, Current / } \\
\text { former smoker with KRAS mutations }\end{array}$ \\
\hline Pack Years & 0.002 & 0.21 & $\begin{array}{l}\text { Low pack year smoking history (mostly never- } \\
\text { smoker regarded as smoking history with } 0 \text { year) } \\
\text { with EGFR mutations. }\end{array}$ \\
\hline Maximum metabolic tumor diameter & 0.26 & 0.66 & - \\
\hline SUVmax & 0.029 & 0.20 & Higher SUVmax with EGFR mutations \\
\hline MTV & 0.16 & 0.09 & - \\
\hline TLG & 0.26 & 0.06 & - \\
\hline $\mathrm{SD}(>1 \mathrm{~cm})$ & 0.16 & 0.94 & - \\
\hline $1 / \mathrm{COV}(>1 \mathrm{~cm})$ & 0.014 & 0.94 & Higher $1 / \mathrm{COV}$ with EGFR mutations \\
\hline $\operatorname{AUC}(>1 \mathrm{~cm})$ & 0.036 & 0.88 & Higher AUC with EGFR mutations \\
\hline $\mathrm{SD}(>2 \mathrm{~cm})$ & 0.07 & 0.70 & - \\
\hline $1 / \operatorname{COV}(>2 \mathrm{~cm})$ & $<0.001$ & 0.73 & Higher $1 / \mathrm{COV}$ with EGFR mutations \\
\hline $\operatorname{AUC}(>3 \mathrm{~cm})$ & 0.012 & 0.45 & - \\
\hline $\mathrm{SD}(>3 \mathrm{~cm})$ & 0.44 & 0.46 & - \\
\hline $1 / \operatorname{COV}(>3 \mathrm{~cm})$ & 0.008 & 0.98 & Higher $1 / \mathrm{COV}$ with EGFR mutations \\
\hline $\operatorname{AUC}(>3 \mathrm{~cm})$ & 0.07 & 0.49 & - \\
\hline
\end{tabular}

MTV: metabolic tumor volume, TLG: total lesion glycolysis, SD: standard deviation, COV: coefficient of variation, AUC: area under the curve of the cumulative SUV-volume Histogram. Measurements within parentheses are indicated maximum metabolic tumor diameter

Table 5: Multivariate analysis for the association between each indexes and EGRF mutation status ( $p$ - values)

\begin{tabular}{lcc}
\hline Index & EGFR mutations & Association \\
\hline Gender & 0.389 & - \\
Smoking status & $<0.001$ & Never - smoker with EGFR mutations \\
(Current/former smoker vs never-smoker) & 0.378 & - \\
SUVmax & 0.456 & - \\
$1 / \operatorname{COV}(>1 \mathrm{~cm})$ & & \\
\hline
\end{tabular}

COV: coefficient of variation.

The advantage for prediction of gene mutation in lung cancer was to select suitable therapeutic strategy for the patient with lung cancer, and it will be desirable if it could be possible by less invasive method. Stiles
B et al. suggested that clinical stage IA lung cancer is frequently under staged in patients [38]. Goldstraw et al. reported that $30 \%$ to $70 \%$ of patients with completely resected disease experienced relapse and/or distant 
Table 6: Number of cases with each index

\begin{tabular}{|c|c|c|c|}
\hline Index & $\begin{array}{c}\text { EGFR mutations } \\
(+/-)\end{array}$ & $\begin{array}{c}\text { KRAS mutations } \\
(+/-)\end{array}$ & $\begin{array}{l}\text { Current/former smoker/never- } \\
\text { smoker }\end{array}$ \\
\hline Age & $32 / 95$ & $31 / 95$ & $22 / 77 / 32$ \\
\hline Gender male & $16 / 66$ & $25 / 59$ & $17 / 56 / 13$ \\
\hline Gender female & $16 / 29$ & $6 / 36$ & $5 / 21 / 19$ \\
\hline Smoking status Current & $1 / 20$ & $8 / 14$ & - \\
\hline Former smoker & $13 / 62$ & $20 / 54$ & - \\
\hline Never-smoker & $18 / 13$ & $3 / 27$ & - \\
\hline Pack Years & $32 / 95$ & $31 / 95$ & $22 / 77 / 32$ \\
\hline Maximum metabolic tumor diameter & $32 / 95$ & $31 / 95$ & $22 / 77 / 32$ \\
\hline SUVmax & $32 / 95$ & $31 / 95$ & $22 / 77 / 32$ \\
\hline MTV & $32 / 95$ & $31 / 95$ & $22 / 77 / 32$ \\
\hline TLG & $32 / 95$ & $31 / 95$ & $22 / 77 / 32$ \\
\hline $\mathrm{SD}(>1 \mathrm{~cm})$ & $27 / 85$ & $28 / 84$ & $20 / 70 / 26$ \\
\hline $1 / \mathrm{COV}(>1 \mathrm{~cm})$ & $27 / 85$ & $28 / 84$ & $20 / 70 / 26$ \\
\hline $\operatorname{AUC}(>1 \mathrm{~cm})$ & $27 / 85$ & $28 / 84$ & $20 / 70 / 26$ \\
\hline $\mathrm{SD}(>2 \mathrm{~cm})$ & $24 / 65$ & $24 / 64$ & $13 / 59 / 21$ \\
\hline $1 / \mathrm{COV}(>2 \mathrm{~cm})$ & $24 / 65$ & $24 / 64$ & $13 / 59 / 21$ \\
\hline $\operatorname{AUC}(>2 \mathrm{~cm})$ & $24 / 65$ & $24 / 64$ & $13 / 59 / 21$ \\
\hline $\mathrm{SD}(>3 \mathrm{~cm})$ & $12 / 42$ & $13 / 40$ & $5 / 37 / 14$ \\
\hline $1 / \mathrm{COV}(>3 \mathrm{~cm})$ & $12 / 42$ & $13 / 40$ & $5 / 37 / 14$ \\
\hline $\operatorname{AUC}(>3 \mathrm{~cm})$ & $12 / 42$ & $13 / 40$ & $5 / 37 / 14$ \\
\hline
\end{tabular}

MTV: metabolic tumor volume, TLG: total lesion glycolysis, SD: standard deviation, COV: coefficient of variation, AUC: area under the curve of the cumulative SUV-volume Histogram. Measurements within parentheses are indicated maximum metabolic tumor diameter

metastases [39]. It appeared that micrometastatic disease had already occurred at the some of cases with early-stage NSCLC.

Therefore, adjuvant and/or neoadjuvant cisplatinbased chemotherapy is advised for patients with early-stage disease [40-42]. Neoadjuvant therapy has advantages for downstaging the tumor before surgery and thus increasing the chances of a complete resection.

Several randomized clinical trials assessed the advantage of neoadjuvant treatment in patients with early stage disease. Although available data suggest a trend in survival benefit in preoperative chemotherapy, the majority of studies showed no statistically significant differences [43].

A phase II study of preoperative gefitinib in clinical stage I non-small-cell lung cancer demonstrated that tumor shrinkage was frequently seen in women, neversmokers and the EGFR expression (proven by biopsy) was a strong predictor of response [44]. Neoadjuvant chemotherapy has also been explored in patients with early-stage NSCLC. It is based on the rationale to be able to decrease micrometastases at distant sites and tumor burden preoperatively to increase resectability and overall survival.

In a systematic review, Nair et al. concluded that increased tumor FDG uptake is associated with poorer survival in patients with stage I NSCLC. FDG uptake has the potential to be used as a biomarker for identifying stage I patients who are at increased risk of death or recurrence and therefore could identify candidates for participation in future trials of adjuvant therapy [45].

However, one of the limitations of neoadjuvant therapy is the inability to confirm gene mutations prior 
to surgical resection. The prediction of gene mutation in lung cancer can be advantageous for selecting patients who would best benefit from neoadjuvant therapy.

The limitation of this study was that we have not yet obtained the result of patient's prognosis, therefore we could not report how FDG PET/CT could predict the prognosis nor its prognostic value when used in conjunction with, or compared against, smoking status.

\section{MATERIALS AND METHODS}

\section{Study population}

The Institutional Review Board and the Stanford Cancer Institute Scientific Review Committee approved this project and protocol. Written informed consent was obtained from all patients before participation in the study. Inclusion criteria were: 1) greater than 18 years-old at the time of radiotracer administration and 2) suspicion of lung cancer on preoperative CT scans by a board-certified radiologist specializing in thoracic imaging. Exclusion criteria were: 1) pneumonic form and central obstructive lesions on preoperative CT which was confirmed by a board-certified radiologist specializing in thoracic imaging.

\section{Clinical data collection}

We collected the following clinical variables from each patient: age, histology, sex and smoking status. After review of the histology of NSCLC, we eliminated subtypes of adenocarcinoma including bronchioloalveolar carcinoma

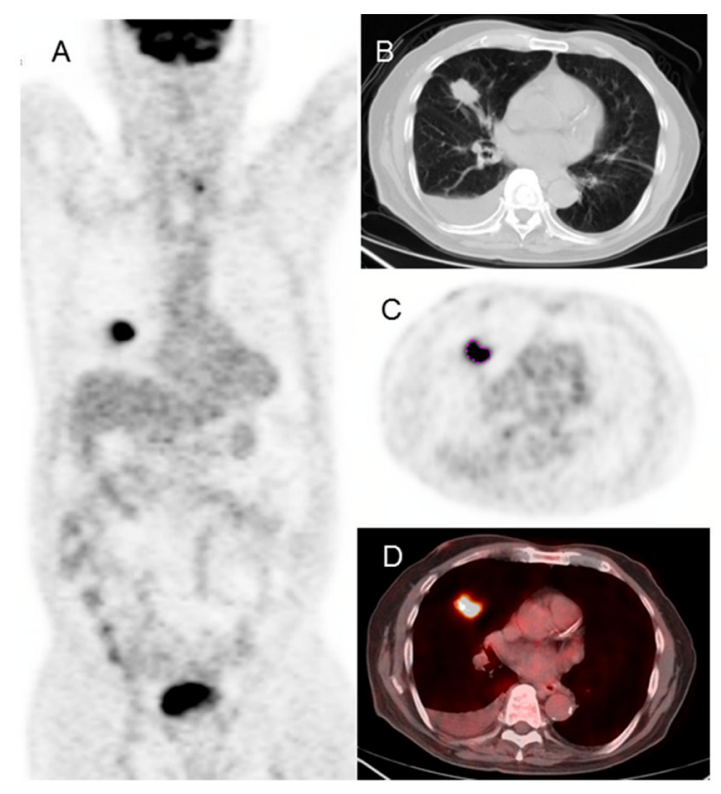

E

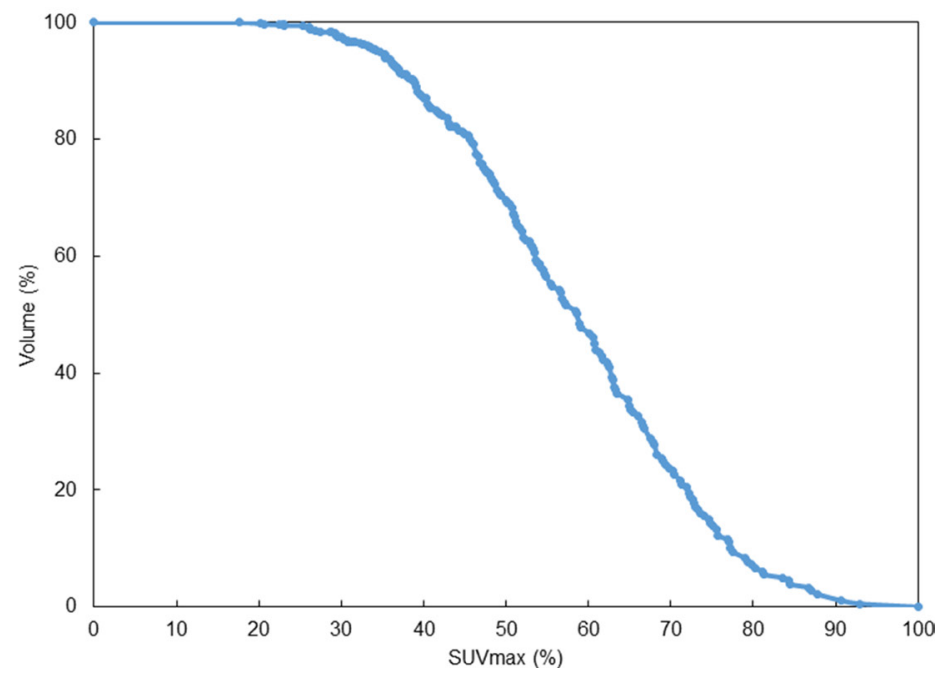

Figure 1: Images and measurement result of FDG PET parameter of lung tumor at right middle lobe. (A) Sagittal whole body PET image, (B) CT portion of PET/CT, (C) PET image (plotted the edge of lung tumor), and (D) fused PET and CT image, (E) cumulative SUV-volume histograms (CSH) : The area under the curve (AUC) of this plot (AUC-CSH) was 0.58. 
(BAC) as defined in the previous pathological classification for lung adenocarcinoma. Smoking status was categorized as never-smoker, former smoker or current smoker.

\section{EGFR and KRAS mutation testing}

The tumor tissues were surgically resected for all patients. Mutation testing was done for both $E G F R$ and $K R A S$ using multiplex PCR followed by single nucleotide mutation detection using SNaPshot technology based on dideoxy single-base extension of oligonucleotide primers [46]. EGFR exons 18, 19, 20 and 21 were tested and $K R A S$ exon 2. Mutations were combined irrespective of their location in the tested exons. Patients were categorized according to the mutation testing as EGFR mutated $(E G F R+)$ and wild-type $E G F R$, and $K R A S$-mutated $(K R A S+)$ and wild-type $K R A S$.

\section{$\mathrm{PET} / \mathrm{CT}$ protocol}

FDG-PET/CT scans were acquired by using a standard clinical protocol at two sites, Stanford University Hospital (SUH) and Veterans Administration Palo Alto Health Care System (VAPAHCS). PET/CT images were acquired using either GE Discovery LS PET/CT (slice thickness, 3-5 mm) (GE Healthcare, Waukesha, WI, USA) at Stanford or GE Discovery VCT (slice thickness, $3.75 \mathrm{~mm}$ ) (GE Health care, Waukesha, WI, USA) at VAPAHCS. At both sites, patients fasted for a minimum of 6 hours, a dose of 12 to 17 millicuries (mCi) of FDG was administered, and patients were scanned from the skull base to mid-thigh using multiple bed positions every 5 minutes approximately 45 to 60 minutes after injection. CT-attenuated data were reconstructed using ordered subset expectation maximization for both scanner sites.

\section{Image analysis}

Representative images are shown in Figure 1. Images were reviewed by two board-certified Nuclear Medicine physicians (RM, AQ) with 8 and 15 years experience respectively. MIMvista 6.2 software (MIMvista Corp, Cleveland, OH, USA) was used to select and measure structures throughout the body using the regionof-interest (ROI) tool within the software. Circular ROIs with a diameter of $10 \mathrm{~mm}$ were drawn on transaxial FDGPET/CT images using the fusion CT scan as an anatomical guide. Background FDG uptake measurement with $10 \mathrm{~mm}$ ROI was conducted for the upper, middle and lower field of lung in both lungs (if a lung lesion happened to exist in the nearby lung field, the measurement was not performed due to the possibility of affected by tumor FDG uptake). For the aortic blood pool, a circular ROI with $10 \mathrm{~mm}$ of diameter was placed centrally within the ascending aorta. For SUV measurements of malignant lesions on PET images, CT images of these lesions were used to confirm the exact location of suspected malignant lesions, with reference to diagnostic chest CT. The PETedge tool within MIMvista 6.2 was used with manual adjustment where needed by consensus of two nuclear medicine physicians for measurements of lung tumor. The longest diameter of identified FDG uptake area by the PETedge tool was measured and was regarded as the metabolic tumor diameter rather than the true diameter. The maximum SUV $\left(\mathrm{SUV}_{\text {max }}\right)$, average SUV ( $\left.\mathrm{SUV}_{\text {mean }}\right)$, standard deviation of SUV metabolic tumor volume (MTV) and total lesion glycolysis (TLG: product of MTV and $\mathrm{SUV}_{\text {mean }}$ ) within a volume of interest (VOI) were recorded. By using these measurement results, inverse coefficient of variation $\left[1 / \mathrm{COV}\right.$, calculated as $\left.\left(\mathrm{SUV}_{\text {mean }} / \mathrm{SD}\right) \times 100 \%\right]$ were additionally calculated as a marker of tumor heterogeneity. Additional metrics for tumor heterogeneity included the calculation of cumulative SUV-volume histograms (CSH) obtained by plotting the percent (SD), volume of a tumor with an SUV above a certain threshold against that threshold, which is varied from 0 to $100 \%$ of SUV max $_{\text {. The }}$ area under the curve (AUC) of this plot (AUC-CSH) is a quantitative index of uptake heterogeneity, where lower values correspond with increased heterogeneity [32].

Tumor heterogeneity analyses were performed only on cases with a metabolic tumor diameter of $10 \mathrm{~mm}$ or more (117 of 131 cases) in order to have an adequate number of pixels within a region- or volume-of-interest.

\section{Statistical analysis}

Mann-Whitney's test was used to compare the difference of PET uptake in normal lung, and PET parameters according to the gene mutation result. We used univariate analysis and multivariate analysis to investigate the relationship between the parameters regarding FDG uptake for lung lesions and the presence of EGFR and $K R A S$ mutations. We also used univariate analysis for the relationship between several indexes and FDG uptake in normal lungs. All statistical analyses were done with Stata 11 (Stata, College Station, TX). Calculated $p$-values were two-sided with a $\mathrm{p}<.05$ considered statistically significant.

\section{CONFLICTS OF INTEREST}

None.

\section{GRANT SUPPORT}

This research was supported by NIH R01CA160251.

\section{REFERENCES}

1. Sharma SV, Bell DW, Settleman J, Haber DA. Epidermal growth factor receptor mutations in lung cancer. Nat Rev Cancer. 2007; 7:169-181. 
2. Rosell R, Moran T, Queralt C, Porta R, Cardenal F, Camps C, Majem M, Lopez-Vivanco G, Isla D, Provencio M, Insa A, Massuti B, Gonzalez-Larriba JL, et al. Screening for epidermal growth factor receptor mutations in lung cancer. N Engl J Med. 2009; 361:958-967.

3. Riely GJ, Marks J, Pao W. KRAS mutations in non-small cell lung cancer. Proc Am Thorac Soc. 2009; 6:201-205.

4. Kwak EL, Bang YJ, Camidge DR, Shaw AT, Solomon B, Maki RG, Ou SH, Dezube BJ, Jänne PA, Costa DB, VarellaGarcia M, Kim WH, Lynch TJ, et al. Anaplastic lymphoma kinase inhibition in non-small-cell lung cancer. N Engl J Med. 2010; 363:1693-1703.

5. Jorissen RN, Walker F, Pouliot N, Garrett TP, Ward CW, Burgess AW. Epidermal growth factor receptor: mechanisms of activation and signalling. Exp Cell Res. 2003; 284:31-53.

6. Yarden Y, Sliwkowski MX. Untangling the ErbB signalling network. Nat Rev Mol Cell Biol. 2001; 2:127-137.

7. Lynch TJ, Bell DW, Sordella R, Gurubhagavatula S, Okimoto RA, Brannigan BW, Harris PL, Haserlat SM, Supko JG, Haluska FG, Louis DN, Christiani DC, Settleman J, et al. Activating mutations in the epidermal growth factor receptor underlying responsiveness of nonsmall-cell lung cancer to gefitinib. N Engl J Med. 2004; 350:2129-139.

8. Paez JG, Janne PA, Lee JC, Tracy S, Greulich H, Gabriel S, Herman P, Kaye FJ, Lindeman N, Boggon TJ, Naoki K, Sasaki H, Fujii Y et al. EGFR mutations in lung cancer: correlation with clinical response to gefitinib therapy. Science. 2004; 304:1497-1500.

9. Pao W, Miller V, Zakowski M, Doherty J, Politi K, Sarkaria I, Singh B, Heelan R, Rusch V, Fulton L, Mardis E, Kupfer D, Wilson R, et al. EGF receptor gene mutations are common in lung cancers from "never smokers" and are associated with sensitivity of tumors to gefitinib and erlotinib. Proc Natl Acad Sci USA. 2004; 101:13306-13011.

10. PaoW, Wang T, Riely G, Miller VA, Pan Q, Ladanyi M, Zakowski MF, Heelan RT, Kris MG, Varmus HE. KRAS mutations and primary resistance of lung adenocarcinomas to gefitinib or erlotinib. PLoS Med. 2005; 2:e17.

11. Sordella R, Bell DW, Haber DA, Settleman J. Gefitinibsensitizing EGFR mutations in lung cancer activate antiapoptotic pathways. Science. 2004; 305:1163-1167.

12. Kohn AD, Summers SA, Birnbaum MJ, Roth RA. Expression of a constitutively active Akt Ser/Thr kinase in 3T3-L1 adipocytes stimulates glucose uptake and glucose transporter 4 translocation. J Biol Chem. 1996; 271:31372-31378.

13. Buzzai M, Bauer DE, Jones RG, Deberardinis RJ, Hatzivassiliou G, Elstrom RL, Thompson CB. The glucose dependence of akt-transformed cells can be reversed by pharmacologic activation of fatty acid betaoxidation. Oncogene. 2005; 24:4165-4173.

14. Elstrom RL, Bauer DE, Buzzai M, Karnauskas R, Harris MH, Plas DR, Zhuang H, Cinalli RM, Alavi A,
Rudin CM, Thompson CB. Akt stimulates aerobic glycolysis in cancer cells. Cancer Res. 2004; 64:3892-3899.

15. Huang CT, Yen RF, Cheng MF, Hsu YC, Wei PF, Tsai YJ, Tsai MF, Shih JY, Yang CH, Yang PC. Correlation of F-18 fluorodeoxyglucose-positron emission tomography maximal standardized uptake value and EGFR mutations in advanced lung adenocarcinoma. Med Oncol. 2010; 27:9-15.

16. Na II, Byun BH, Kim KM, Cheon GJ, Choe du H, Koh JS, Lee DY, Ryoo BY, Baek H, Lim SM, Yang SH, Kim CH, Lee JC. 18F-FDG uptake and EGFR mutations in patients with non-small cell lung cancer: a single-institution retrospective analysis. Lung Cancer. 2010; 67:76-80.

17. Caicedo C, Garcia-Velloso MJ, Lozano MD, Labiano T, Vigil Diaz C, Lopez-Picazo JM, Gurpide A, Zulueta JJ, Richter Echevarria JA, Perez Gracia JL. Role of [18F] FDG PET in prediction of KRAS and EGFR mutation status in patients with advanced non-small-cell lung cancer. Eur J Nucl Med Mol Imaging. 2014; 41:2058-2065.

18. Fidler IJ, Hart, IR. Biological diversity in metastatic neoplasms: origins and implications. Science. 1982; 217:998-1003.

19. Bedard PL, Hansen AR, Ratain MJ, Siu LL. Tumour heterogeneity in the clinic. Nature. 2013; 501:355-364.

20. Taniguchi K, Okami J, Kodama K, Higashiyama M, Kato K. Intratumor heterogeneity of epidermal growth factor receptor mutations in lung cancer and its correlation to the response to gefitinib. Cancer Sci. 2008; 99:929-935.

21. Sakurada A, Lara-Guerra H, Liu N, Shepherd FA, Tsao MS. Tissue heterogeneity of EGFR mutation in lung adenocarcinoma. J Thorac Oncol. 2008; 3:527-529.

22. Sørensen M, Horsman MR, Cumming P, Munk OL, Keiding S. Effect of intratumoral heterogeneity in oxygenation status on FMISO PET, autoradiography, and electrode Po2 measurements in murine tumors. Int J Radiat Oncol Biol Phys. 2005; 62:854-861.

23. Minamimoto R, Toyohara J, Seike A, Ito H, Endo H, Morooka M, Nakajima K, Mitsumoto T, Ito K, Okasaki M, Ishiwata K, Kubota K. 4'-[Methyl-11C]-thiothymidine $\mathrm{PET} / \mathrm{CT}$ for proliferation imaging in non-small cell lung cancer. J Nucl Med. 2012; 53:199-206.

24. Zhao S, Kuge Y, Mochizuki T, Takahashi T, Nakada K, Sato M, Takei T, Tamaki N. Biologic correlates of intratumoral heterogeneity in $18 \mathrm{~F}-\mathrm{FDG}$ distribution with regional expression of glucose transporters and hexokinaseII in experimental tumor. J Nucl Med. 2005; 46:675-682.

25. Yang Z, Tang LH, Klimstra DS. Effect of tumor heterogeneity on the assessment of Ki67 labeling index in well-differentiated neuroendocrine tumors metastatic to the liver: implications for prognostic stratification. Am J Surg Pathol. 2011; 35:853-860.

26. Pham D, Kris MG, Riely GJ, Sarkaria IS, McDonough T, Chuai S, Venkatraman ES, Miller VA, Ladanyi M, Pao W, Wilson RK, Singh B, Rusch VW. Use of cigarette-smoking 
history to estimate the likelihood of mutations in epidermal growth factor receptor gene exons 19 and 21 in lung adenocarcinomas. J Clin Oncol. 2006; 24:1700-1704.

27. Riely GJ, Kris MG, Rosenbaum D, Marks J, Li A, Chitale DA, Nafa K, Riedel ER, Hsu M, Pao W, Miller VA, Ladanyi M. Frequency and distinctive spectrum of KRAS mutations in never smokers with lung adenocarcinoma. Clin Cancer Res. 2008; 14:5731-534.

28. Mak RH, Digumarthy SR, Muzikansky A, Engelman JA, Shepard JA, Choi NC, Sequist LV. Role of $18 \mathrm{~F}$-fluorodeoxyglucose positron emission tomography in predicting epidermal growth factor receptor mutations in non-small cell lung cancer. Oncologist. 2011; 16:319-326.

29. Park EA, Lee HJ, Kim YT, Kang CH, Kang KW, Jeon YK, Goo JM, Lee CH, Park CM. EGFR gene copy number in adenocarcinoma of the lung by FISH analysis: investigation of significantly related factors on CT, FDGPET, and histopathology. Lung Cancer. 2009; 64:179-186.

30. Lee SM, Bae SK, Jung SJ, Kim CK. FDG Uptake in NonSmall Cell Lung Cancer Is Not an Independent Predictor of EGFR or KRAS Mutation Status: A Retrospective Analysis of 206 Patients. Clin Nucl Med. 2015; 40:950-958.

31. Nishino M, Hatabu H, Johnson BE, McLoud TC. State of the art: Response assessment in lung cancer in the era of genomic medicine. Radiology. 2014; 271:6-27.

32. van Velden FH, Cheebsumon P, Yaqub M, Smit EF, Hoekstra OS, Lammertsma AA, Boellaard R. Evaluation of a cumulative SUV-volume histogram method for parameterizing heterogeneous intratumoural FDG uptake in non-small cell lung cancer PET studies. Eur J Nucl Med Mol Imaging. 2011; 38:1636-1647.

33. Yip SS, Kim J, Coroller TP, Parmar C, Velazquez ER, Huynh E, Mak RH, Aerts HJ. Associations Between Somatic Mutations and Metabolic Imaging Phenotypes in Non-Small Cell Lung Cancer. J Nucl Med. 2017; 58:569-76.

34. Tixier F, Hatt M, Le Rest CC, Le Pogam A, Corcos L, Visvikis D. Reproducibility of tumor uptake heterogeneity characterization through textural feature analysis in 18F-FDG PET. J Nucl Med. 2012; 53:693-700.

35. Galavis PE, Hollensen C, Jallow N, Paliwal B, Jeraj R. Variability of textural features in FDG PET images due to different acquisition modes and reconstruction parameters. Acta Oncol. 2010; 49:1012-1016.

36. Shen G, Nelson D, Adler L. PET Tumor Segmentation: Comparison of gradient-based algorithm to constant threshold algorithm. Med Phys. 2007; 34:2395

37. Nelson AD, Werner-Wasik M, Choi W, Arai Y, Faulhaber PF, Ohri N, Piper JW, Brockway KD, Nelson AS. PET Tumor Segmentation: Multi-observer Validation of a Gradient-Based Method using a NSCLC PET Phantom. Int J Radiat Oncol Biol Phys. 2009; 75:S627.

38. Stiles BM, Servais EL, Lee PC, Port JL, Paul S, Altorki NK. Point: Clinical stage IA non-small cell lung cancer determined by computed tomography and positron emission tomography is frequently not pathologic IA non-small cell lung cancer: the problem of understaging. J Thorac Cardiovasc Surg. 2009; 137:13-19.

39. Goldstraw P, Crowley J, Chansky K, Giroux DJ, Groome PA, Rami-Porta R, Postmus PE, Rusch V, Sobin L, and International Association for the Study of Lung Cancer International Staging Committee, and Participating Institutions. The IASLC Lung Cancer Staging Project: proposals for the revision of the TNM stage groupings in the forthcoming (seventh) edition of the TNM classification of malignant tumours. J Thorac Oncol. 2007; 2:706-714.

40. Pignon JP, Tribodet H, Scagliotti GV, Douillard JY, Shepherd FA, Stephens RJ, Dunant A, Torri V, Rosell R, Seymour L, Spiro SG, Rolland E, Fossati R, et al. Lung adjuvant cisplatin evaluation: a pooled analysis by the LACE Collaborative Group. J Clin Oncol. 2008; 26:3552-3559.

41. Roth JA, Fossella F, Komaki R, Ryan MB, Putnam JB Jr, Lee JS, Dhingra H, De Caro L, Chasen M, McGavran M. A randomized tria comparing perioperative chemotherapy and surgery with surgery alone in resectable stage IIIA nonsmall-cell lung cancer. J Natl Cancer Inst. 1994; 86:673-680.

42. Rosell R, Gómez-Codina J, Camps C, Maestre J, Padille J, Cantó A, Mate JL, Li S, Roig J, Olazábal A. A randomized trial comparing preoperative chemotherapy plus surgery with surgery alone in patients with non-small-cell lung cancer. N Engl J Med. 1994; 330:153-158.

43. Crinò L, Weder W, van Meerbeeck J, Felip E; ESMO Guidelines Working Group. Early stage and locally advanced (non-metastatic) non-small-cell lung cancer: ESMO Clinical Practice Guidelines for diagnosis, treatment and follow-up. Ann Oncol. 2010; 21:v103-115.

44. Lara-Guerra H, Waddell TK, Salvarrey MA, Joshua AM, Chung CT, Paul N, Boerner S, Sakurada A, Ludkovski O, Ma C, Squire J, Liu G, Shepherd FA, et al. Phase II study of preoperative gefitinib in clinical stage I non-small-cell lung cancer. J Clin Oncol. 2009; 27:6229-36.

45. Nair VS, Krupitskaya Y, Gould MK. Positron emission tomography $18 \mathrm{~F}$-fluorodeoxyglucose uptake and prognosis in patients with surgically treated, stage I non-small cell lung cancer: a systematic review. J Thorac Oncol. 2009; 4:1473-1479.

46. Dias-Santagata D, Akhavanfard S, David SS, Vernovsky K, Kuhlmann G, Boisvert SL, Stubbs H, McDermott U, Settleman J, Kwak EL, Clark JW, Isakoff SJ, Sequist LV, et al. Rapid targeted mutational analysis of human tumours: a clinical platform to guide personalized cancer medicine. EMBO Mol Med. 2010; 2:146-58. 